\title{
HUBUNGAN ANTARA KEKUATAN OTOT TUNGKAIKESEIMBANGAN \\ DINAMIS DAN KELENTUKANDENGAN KETEPATANPASSING \\ SEPAKBOLA PADA PEMAINPUTRAUMUR 14-15 TAHUN \\ KLUB SSB ANGKASA SOLO TAHUN 2019.
}

\section{Oleh Risa Agus Teguh Wibowo}

\begin{abstract}
ABSTRAK
Tujuan dari penelitian ini adalah untuk mengetahui: (1) Hubungan antara Kekuatan Otot TungkaiDengan Ketepatan Passing Pada Pemain Putra Umur 1415 Tahun Klub SSB Angkasa Solo Tahun 2019. (2) Hubungan antara Keseimbangan Dinamis Dengan Ketepatan Passing Pada Pemain Putra Umur 1415 Tahun Klub SSB Angkasa Solo Tahun 2019. (3) Hubungan antara Kelentukan Dengan Ketepatan Passing Pada Pemain Putra Umur 14-15 Tahun Klub SSB Angkasa Solo Tahun 2019. (4) Hubungan antara Kekuatan Otot TungkaiKeseimbangan Dinamis Dan KelentukanDengan Ketepatan Passing Pada Pemain Putra Umur 14-15 Tahun Klub SSB Angkasa Solo Tahun 2019.

Penelitian ini dilaksanakan di SSB Angkasa Solo dan penelitian ini dilaksanakan pada bulan September tahun 2019. Dalam penelitian ini variabel bebas disebut juga sebagai prediktor dan variabel terikat yang disebut juga sebagai kriterium. Teknik pengumpulan data dalam penelitian ini adalah menggunakan teknik tes dan pengukuran. Adapun jenis tes yang digunakan adalah: (1) Tes dan kekuatan otot tungkai dengan leg dynamometer (Widiastuti 2015:80). (2) Tes dan pengukuran keseimbangan dinamis dengan modifikasi bass test (Ismaryati, 2008: 51-53). (3) Tes dan pengukuran kelentukan dengan sit and reach(Ismaryati, 2008: 101-102). (4) Tes dan pengukuran ketepatan passing bola diukur dengan tes passing bola dari Siem Ployer (Soekatamsi, 2000:623).Petunjuk peleksanaan masing-masing tes terlampir.
\end{abstract}

Berdasarkan analisis data dan pengujian hipotesis yang telah dilakukan, maka simpulan yang dapat diperoleh adalah: (1) Ada hubungan yang signifikanantara Kekuatan Otot Tungkai dengan Ketepatan Passing, $\mathrm{r}_{\text {hitung }}=0.426$ $>\mathrm{r}_{\text {tabel }} 5 \%=0,361$. (2) Ada hubungan yang signifikan antara Keseimbangan Dinamisdengan Ketepatan Passing, $\mathrm{r}_{\text {hitung }}=0.494>\mathrm{r}_{\text {tabel }} 5 \%=0,361$. (3) Ada hubungan yang signifikan antara Kelentukan dengan Ketepatan Passing r tabel, $\mathrm{r}_{\text {hitung }}=0.491>\mathrm{r}_{\text {tabel }} 5 \%=0,361$. (4) Ada hubungan yang signifikan antara Kekuatan Otot Tungkai, Keseimbangan Dinamisdan Kelentukan dengan

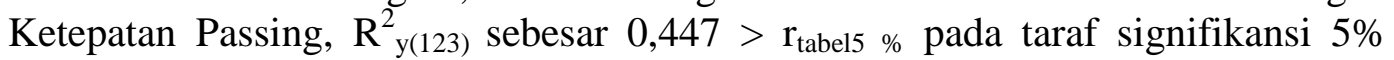
sebesar 0.361 dan $\mathrm{F}_{0}$ sebesar $7.0183>\mathrm{f}_{\text {tabel }}$ pada taraf signifikansi $5 \%$ sebesar 2,89 .

Kata Kunci : Kekuatan Otot Tungkai, Keseimbangan Dinamis, Kelentukan, Ketepatan Passing. 


\section{Hubungan Antara Kekuatan Otot Tungkai keseimbangan Dinamis Dan Kelentukan dengan Ketepatan passing Sepakbola Pada Pemain putra umur 14-15 Tahun Klub SSB Angkasa Solo Tahun 2019 (Risa Agus Teguh Wibowo)}

\section{A. PENDAHULUAN}

Arahan pembinaan usia dini dalam bidang olahraga di Indonesia saat ini belum maksimal. Hal ini terbukti dari hasil kejuaraan-kejuaraan yang telah diikuti belum menunjukkan hasil yang memuaskan. Proses pembinan olahraga ini harusnya dipahami sebagai suatu sistem yang kompleks, sehingga masalah yang terdapat didalamnya perlu ditelaah dari sudut pandang yang luas. Pembinaan sebagaimana yang dimaksud antara lain dapat dilakukan pada aspek gerakan. Gerakan-gerakan dalam bidang olahraga diharapkan dilakukan dengan cara efisien, dan teknik yang benar. Seseorang yang mampu melakukan gerakangerakan secara efisien, orang tersebut dapat dikatakan terampil.

Menurut Sudjarwo (1995: 9-10) mengemukakan "Dalam usaha pencapaian prestasi maksimal sebenarnya ada dua faktor yang menentukan, yakni faktor indogen dan faktor eksogen. Faktor indogen adalah beberapa aspek yang harus dipenuhi oleh seseorang atlet untuk dapat mencapai prestasi maksimal seperti bentuk dan proporsi tubuh yang sesuai dengan cabang olahraganya, kemampuan fisik, kesehatan. Faktor eksogen adalah faktor diluar atlet yang mempengaruhi pencapaian prestasi maksimal seperti interaksi antara pelatih dan atlet, lingkungan hidup yang menunjang."

Melihat setiap aktivitas manusia dalam berolahraga selalu melibatkan kondisi fisik atau keadaan tubuh yang prima. Kondisi fisik adalah suatu kesatuan utuh dari komponen-komponen yang tidak dapat dipisahkan begitu saja, baik peningkatan maupun pemeliharaannya. Selanjutnya bahwa kondisi fisik adalah satu prasyarat yang sangat diperlukan dalam usaha peningkatan prestasi seorang pemain, bahkan dapat dikatakan sebagai keperluan yang tidak dapat ditunda atau ditawar-tawar lagi (Mochamad Sajoto, 1995: 8).

Untuk mewujudkan peningkatan prestasi olahragawan, maka dilakukan berbagai upaya serta pendekatan yang strategis, induk organisasi sepakbola di Indonesia dan masyarakat. Upaya pembinaan dan pengembangan sepakbola yang diselenggarakan melalui jalur sekolah, luar sekolah maupun melalui perkumpulan- 


\section{Hubungan Antara Kekuatan Otot Tungkai keseimbangan Dinamis Dan Kelentukan dengan Ketepatan passing Sepakbola Pada Pemain putra umur 14-15 Tahun Klub SSB Angkasa Solo Tahun 2019 (Risa Agus Teguh Wibowo)}

perkumpulan atau klub-klub yang ada, mengalami pasang surut dan tidak berjalan mulus seperti yang diharapkan. Sepakbola sebagai aktivitas jasmani merupakan salah satu cabang olahraga yang populer dan berkembang pesat di Indonesia. Banyak orang melakukan olahraga sepakbola dengan berbagai macam tujuan, diantaranya untuk rekreasi dan hiburan, menjaga kebugaran dan kesehatan sampai untuk tujuan olahraga prestasi. Sebagai cabang olahraga prestasi, sepakbola termasuk olahraga kompetitif yang memerlukan gerakan eksplosif, banyak gerakan refleks, kecepatan merubah arah dan juga membutuhkan motor ability yang baik.

Faktor yang dapat memacu perkembangan prestasi dalam olahraga diantaranya adalah adanya peningkatan kualitas dalam pelatihan dan pembinaan olahraga. Peningkatan kualitas dalam pelatihan dan pembinaan olahraga tersebut dapat dicapai dengan penerapan berbagai disiplin ilmu dan teknologi yang terkait dalam pelatihan dan pembinaan olahraga. Upaya pencapaian prestasi dalam olahraga, harus melalui latihan yang dilakukan dengan pendekatan ilmiah terhadap ilmuilmu yang terkait. Tujuan utama dari permainan sepak bola adalah untuk mencari kemenangan. Satu kesebelasan dikatakan menang apabila berhasil memasukkan bola lebih banyak ke gawang lawannya. Salah satu cara untuk memasukkan bola ke dalam gawang diawali dengan Passing kepada teman yang berdiri bebas untuk segera melakukan tendangan langsung ke arah gawang atau dengan cara menyundul bola. Teknik dasar Passing kepada teman akan dapat dilakukan dengan adanya kemampuan kondisi fisik dari pemain yang melakukan.

Untuk peningkatan prestasi olahraga sepakbola khususnya pada klub SSB Angkasa Solodiperlukan latihan yang intensif. Pembinaannya meliputi faktor fisik, teknik, taktik dan mental. Selama ini pada latihan yang diberikan lebih menekankan pada faktor teknik. Sedangkan kondisi fisik belum dibina secara maksimal, hal ini bisa disebabkan bahwa faktor fisik dianggap telah terwakili pada saat latihan sehingga kondisi fisik secara otomatis meningkat. Anggapan tersebut kurang benar, karena sepakbola memerlukan unsur kondisi fisik tersendiri sehingga membutuhkan pembinaan fisik yang lebih tepat. Unsur kondisi fisik yang diperlukan pada sepakbola antara lain, power, kekuatan, kecepatan, 


\section{Hubungan Antara Kekuatan Otot Tungkai keseimbangan Dinamis Dan Kelentukan dengan Ketepatan passing Sepakbola Pada Pemain putra umur 14-15 Tahun Klub SSB Angkasa Solo Tahun 2019 (Risa Agus Teguh Wibowo)}

kelincahan, kelenturan, koordinasi, fleksibilitas, keseimbangan, ketepatan dan daya tahan.

Klub SSB Angkasa Solo merupakan salah satu perkumpulan sepakbola yang memiliki kelebihan dan kekurangan dibanding dengan perkumpulan-perkumpulan sepakbola yang lain. Kelebihan-kelebihan tersebut diantaranya adalah memiliki pemain yang rata-rata kompetensi keterampilannya baik, fasilitas olahraga cukup, tetapi prestasi cabang olahraga sepakbola masih rendah atau masih jarang menjadi juara padahal setiap even pertandingan selalu mengikutinya. Pemain kelompok umur 14-15 Tahun SSB Angkasa Solo dalam ketepatan Passing bola sering kurang maksimal sehingga banyak peluang terbuang dalam proses mencetak gol.

Ketepatan Passing bola memiliki tingkat kerumitan dan kompleksitas yang berbeda-beda, baik dari keterampilan yang mudah sampai keterampilan yang semakin sulit, dan dari keterampilan yang sederhana sampai pada keterampilan yang kompleks. Dipandang dari tingkat kesulitan dan kompleksitas, ketepatan Passing bola memiliki tingkat kesulitan dan kompleksitas yang tinggi karena mencakup unsur-unsur: koordinasi, timing, tempo, keseimbangan dan akurasi. Ketepatan Passing bola merupakan suatu teknik dasar yang harus dikuasai setiap pemain sepakbola tanpa terkecuali. Ketepatan Passing bola adalah suatu teknik dasar Passing yang sering digunakan oleh setiap pemain untuk menjalankan proses dalam mencetak gol dalam setiap pertandingan. Ketepatan Passing bola dapat dilakukan oleh setiap pemain, biasanya dalam suatu tim sepakbola mempunyai kekompakan tersendiri dalam melakukan Passing bola. Ketepatan Passing bola harus dimiliki oleh seorang pemain tanpa terkecuali sebagai modal utama dalam melakukan permainan sampai terjadinya proses gol dalam sepakbola.

Ketepatan Passing bola merupakan salah teknik dasar dalam sepakbola namun cukup sulit dipelajari, lebih-lebih untuk pemain yang belum terampil dan belum terlatih gerak Passing bola secara refleks. Tujuan dalam permainan sepakbola adalah untuk menciptakan proses Passing yang tepat dan mendapat angka pada setiap kesempatan, yang merupakan syarat tim tersebut dinyatakan pemenang. Dengan demikian keterampilan gerak dasar Passing dalam permainan 


\section{Hubungan Antara Kekuatan Otot Tungkai keseimbangan Dinamis Dan Kelentukan dengan Ketepatan passing Sepakbola Pada Pemain putra umur 14-15 Tahun Klub SSB Angkasa Solo Tahun 2019 (Risa Agus Teguh Wibowo)}

sepakbola sangat penting untuk dikuasai secara baik, tetapi tidak boleh mengesampingkan keterampilan gerak dasar yang lain. Tingkat keberhasilan pemain memasukkan bola ke gawang dapat dipengaruhi oleh kebiasaan dan penguasaan teknik Passing yang baik, baik Passing pendek maupun Passing jarak jauh.

Dalam ketepatan Passing bola merupakan dasar yang sulit dipelajari, lebih-lebih untuk pemain yang belum terampil. Agar ketepatan Passing bola dapat dilakukan dengan baik, terlebih dahulu perlu dikaji faktor-faktor yang mempengaruhi ketepatan Passing bola perlu ditelusuri faktor penyebabnya. Dimana faktor-faktor yang mempengaruhi ketepatan Passing bola diperlukan unsur-unsur kondisi fisik seperti: kekuatan, kecepatan, kelenturan, keseimbangan, ketepatan, daya tahan, kelincahan, dan koordinasi.

Perbedaan kemampuan terutama terjadi karena kualitas fisik yang berbeda (Sugiyanto, 1997: 353). Kemampuan fisik berhubungan dengan keseimbangan dinamis dan kelentukan yang mempengaruhi penampilan seseorang baik dalam latihan gerakan-gerakan keterampilan maupun dalam penampilan. Begitu juga dengan kekuatan otot tungkai yang mempengaruhi keterampilan pemain. Dengan demikian dapat dikatakan kekuatan otot tungkai, keseimbangan dinamis, dan kelentukan adalah suatu persyaratan dalam usaha mencapai prestasi maksimal bagi seseorang dalam latihan ketepatan Passing bola. Kekuatan otot tungkai, keseimbangan dinamis, dan kelentukan yang ada pada pemain putra harus menjadi pertimbangan sebagai suatu faktor yang menentukan dalam ketepatan Passing bola yang sesuai dengan karakter dari masing-masing pemain sehingga bisa mencapai hasil latihan yang optimal sesuai dengan potensi yang dimiliki.

\section{B. METODE PENELITIAN}

Metode penelitian yang digunakan adalah metode deskriptif studi korelasional. Dalam hal ini Ali Maksum (2012: 68) berpendapat bahwa "melalui studi korelasional dapat diketahui apakah satu variabel berasosiasi dengan variabel yang lain. Hubungan antara variabel ditentukan dengan menggunakan koefisien yang dihitung dengan teknik analisis statistik". Penelitian ini untuk 
mengetahui hubungan antara kekuatan otot tungkai, keseimbangan dinamis, dan kelentukan dengan ketepatan Passing bola

\section{HASIL PENELITIAN}

\section{A. Deskripsi Data}

Data yang diperoleh dari tiap-tiap variabel tersebut kemudian dikelompokkan dan dianalisis dengan statistik, seperti terlihat pada lampiran. Adapun rangkuman deskripsi data secara keseluruhan akan disajikan sebagai berikut:

Tabel 1.Deskripsi Data Hasil Tes Kekuatan Otot Tungkai, Keseimbangan Dinamisdan Kelentukan dan Kemampuan Passing.

\begin{tabular}{|c|c|c|c|c|c|c|}
\hline Variabel & Tes & $\mathrm{N}$ & Mean & $\mathrm{SD}$ & $\begin{array}{c}\text { Nilai } \\
\text { Tertinggi }\end{array}$ & $\begin{array}{c}\text { Nilai } \\
\text { Terendah }\end{array}$ \\
\hline $\begin{array}{c}\text { Kekuatan Otot } \\
\text { Tungkai }\end{array}$ & Test & 30 & 40.23 & 2.21 & 45 & 37 \\
\cline { 2 - 7 } & Re-test & 30 & 41.00 & 1.97 & 44 & 38 \\
\hline $\begin{array}{c}\text { Keseimbangan } \\
\text { Dinamis }\end{array}$ & Test & 30 & 84.07 & 6.11 & 95 & 75 \\
\cline { 2 - 7 } & Re-test & 30 & 85.93 & 5.99 & 98 & 77 \\
\hline \multirow{2}{*}{\begin{tabular}{c} 
Kelentukan \\
\cline { 2 - 7 } Kemampuan Passing
\end{tabular}} & Test & 30 & 32.83 & 2.53 & 38 & 30 \\
\cline { 2 - 7 } & Re-test & 30 & 33.70 & 2.32 & 38 & 30 \\
\cline { 2 - 7 } & Re-test & 30 & 7.37 & 1.71 & 10 & 4 \\
\hline
\end{tabular}

\section{B. Uji Reliabilitas}

Uji reliabilitas bertujuan untuk mengetahui tingkat keajegan hasil tes masing-masing variabel yang dilakukan dalam penelitian. Hasil uji reliabilitas tes dan re-testKekuatan Otot Tungkai, Keseimbangan Dinamisdan Kelentukan dan Kemampuan Passing kemudian dikategorikan, dengan menggunakan pedoman tabel koefisien korelasi dari Book Walter yang dikutip Mulyono BiyaktoAtmojo (2008:22), yaitu: 
Tabel 2. Range Kategori Reliabilitas

\begin{tabular}{|c|c|}
\hline Kategori & Reliabilitas \\
\hline Tinggi Sekali & $0,90-1,00$ \\
\hline Tinggi & $0,80-0,89$ \\
\hline Cukup & $0,60-0,79$ \\
\hline Kurang & $0,40-0,59$ \\
\hline Tidak Signifikan & $0,00-0,39$ \\
\hline
\end{tabular}

Hasil uji reliabilitas data Kekuatan Otot Tungkai, Keseimbangan Dinamisdan Kelentukan dan Kemampuan Passing pada penelitian ini adalah:

Tabel 3. Ringkasan Hasil Uji Reliabilitas Data

\begin{tabular}{|l|c|c|}
\hline \multicolumn{1}{|c|}{ Variabel } & Reliabilita & Kategori \\
\hline Kekuatan Otot Tungkai & 0.906 & Tinggi Sekali \\
\hline Keseimbangan Dinamis & 0.998 & Tinggi Sekali \\
\hline Kelentukan & 0.788 & Cukup \\
\hline Kemampuan Passing & 0.978 & Tinggi Sekali \\
\hline
\end{tabular}

\section{Pengujian Persyaratan Analisis}

Sebelum analisis data dilakukan uji persyaratan analisis. Untuk analisis regresi diperlukan uji persyaratan analisis yaitu normalitas penyebarannilai dan persyaratan linieritas hubungan antara prediktor dengan kriterium. Hasil pengujian persyaratan analisis pada penelitian ini adalah sebagai berikut:

\section{Uji Normalitas}

Uji normalitas data dalam penelitian ini menggunakan chi-kuadrat. Adapun hasil uji normalitas yang dilKelentukankan pada hasil tes Kekuatan Otot Tungkai $\left(\mathrm{X}_{1}\right)$, Keseimbangan Dinamis $\left(\mathrm{X}_{2}\right)$, Kelentukan $\left(\mathrm{X}_{3}\right)$ dan Kemampuan Passing (Y) pada penelitian ini adalah: 
Tabel 4. Rangkuman Hasil Uji Normalitas Data

\begin{tabular}{|c|c|c|c|c|c|c|}
\hline Variabel & $\mathrm{Db}$ & $\mathrm{M}$ & $\mathrm{SD}$ & $\chi_{\text {hitung }}^{2}$ & $\chi_{\text {tabel 5\% }}^{2}$ & Simpulan \\
\hline $\begin{array}{l}\text { Kekuatan Otot } \\
\text { Tungkai }\end{array}$ & $\begin{array}{c}6-1= \\
5\end{array}$ & 40.23 & 2.21 & 2.578 & 11,070 & $\begin{array}{c}\text { Berdistribusi } \\
\text { normal }\end{array}$ \\
\hline $\begin{array}{l}\text { Keseimbangan } \\
\text { Dinamis }\end{array}$ & $\begin{array}{c}6-1= \\
5\end{array}$ & 84.07 & 6.11 & 3.245 & 11,070 & $\begin{array}{c}\text { Berdistribusi } \\
\text { normal }\end{array}$ \\
\hline Kelentukan & $\begin{array}{c}6-1= \\
5\end{array}$ & 32.83 & 2.53 & 2.358 & 11,070 & $\begin{array}{c}\text { Berdistribusi } \\
\text { normal }\end{array}$ \\
\hline $\begin{array}{l}\text { Kemampuan } \\
\text { Passing }\end{array}$ & $\begin{array}{c}6-1= \\
5\end{array}$ & 5.43 & 1.74 & 2.167 & 11,070 & $\begin{array}{c}\text { Berdistribusi } \\
\text { normal }\end{array}$ \\
\hline
\end{tabular}

Dari hasil uji normalitas yang dilakukan pada tiap-tiap variabel tersebut dapat diketahui bahwa nilai $c h i$-kuadrat yang diperoleh $\left(\chi^{2}\right.$ hitung $)$ pada variabel Kekuatan Otot Tungkai $\left(\mathrm{X}_{1}\right)$, Keseimbangan Dinamis $\left(\mathrm{X}_{2}\right)$, Kelentukan $\left(\mathrm{X}_{3}\right)$ dan Kemampuan Passing (Y) lebih kecil dari nilai chikuadrat dalam tabel $\left(\chi_{\text {tabel }}^{2} \%\right)$. Dengan demikian hipotesis nol diterima. Yang berarti bahwa data hasil tes Kekuatan Otot Tungkai $\left(\mathrm{X}_{1}\right)$, Keseimbangan Dinamis $\left(\mathrm{X}_{2}\right)$, Kelentukan $\left(\mathrm{X}_{3}\right)$ dan Kemampuan Passing (Y) termasuk berdistribusi normal.

\section{Uji Linieritas}

Uji linieritas hubungan antara masing-masing prediktor yaitu Kekuatan Otot Tungkai $\left(\mathrm{X}_{1}\right)$, Keseimbangan Dinamis $\left(\mathrm{X}_{2}\right)$, Kelentukan $\left(\mathrm{X}_{3}\right)$, dengan kriterium yaitu KetepatanPassing (Y) dilakukan dengan analisis varians. Rangkuman hasil uji linieritas tersebut dapat dilihat dalam tabel sebagai berikut:

Tabel 5. Rangkuman Hasil Analisis Varians Untuk Uji Linieritas Hubungan Antara Prediktor dengan Kriterium

\begin{tabular}{|c|c|c|c|c|}
\hline Variabel & $\mathrm{db}$ & $\mathrm{F}_{\text {hitung }}$ & $\mathrm{F}_{\text {tabel5\% }}$ & Simpulan \\
\hline $\mathrm{X}_{1} \mathrm{Y}$ & $4: 24$ & 0.51 & 2,78 & Model linier diterima \\
\hline $\mathrm{X}_{2} \mathrm{Y}$ & $13: 15$ & 0.92 & 2,43 & Model linier diterima \\
\hline $\mathrm{X}_{3} \mathrm{Y}$ & $20: 8$ & 1.21 & 3,15 & Model linier diterima \\
\hline
\end{tabular}


Dari rangkuman hasil uji linieritas tersebut dapat diketahui bahwa nilai $\mathrm{F}_{\text {hitung }}$ linieritas yang diperoleh dari tiap variabel lebih kecil dari harga $\mathrm{F}_{\text {tabel }}$ 5\%. Dengan demikian hipotesis nol linieritas ketiga variabel tersebut diterima. Berarti bahwa baik korelasi antara $\mathrm{X}_{1} \mathrm{Y}, \mathrm{X}_{2} \mathrm{Y}$ dan $\mathrm{X}_{3} \mathrm{Y}$ berbentuk linier.

\section{Hasil Analisis Data}

Hasil analisis korelasi dan analisis regresi antara data tes Kekuatan Otot Tungkai $\left(\mathrm{X}_{1}\right)$, Keseimbangan Dinamis $\left(\mathrm{X}_{2}\right)$, Kelentukan $\left(\mathrm{X}_{3}\right)$ dengan Ketepatan Passing (Y) penelitian ini adalah:

\section{Analisis Korelasi Tiap Prediktor}

Hasil analisis korelasi masing-masing prediktor dengan kriterium penelitian ini adalah sebagai berikut:

a. Berdasarkan analisis korelasi antara Kekuatan Otot Tungkai $\left(\mathrm{X}_{1}\right)$ dengan Kemampuan Passing (Y), diperoleh koefisien korelasi sebesar 0.426. Dengan $\mathrm{N}=30$, nilai $\mathrm{r}_{\text {tabel }} \%=0,361$. Ternyata $\mathrm{r}_{\text {hitung }}=0.426>\mathrm{r}_{\text {tabel }} \%=$ 0,361. Hal ini menunjukkan bahwa terdapat hubungan yang signifikan antara Kekuatan Otot Tungkai $\left(\mathrm{X}_{1}\right)$ dengan KetepatanPassing (Y).

b. Berdasarkan analisis korelasi antara Keseimbangan Dinamis $\left(\mathrm{X}_{2}\right)$ dengan Kemampuan Passing (Y), diperoleh koefisien korelasi sebesar 0.494. Dengan $\mathrm{N}=30$, nilai $\mathrm{r}_{\text {tabel }} \%=0,361$. Ternyata $\mathrm{r}_{\text {hitung }}=0.494>\mathrm{r}_{\text {tabel }} \%=$ 0,361. Hal ini menunjukkan bahwa terdapat hubungan yang signifikan antara Keseimbangan Dinamis $\left(\mathrm{X}_{2}\right)$ dengan KetepatanPassing $(\mathrm{Y})$.

c. Berdasarkan analisis korelasi antara Kelentukan $\left(\mathrm{X}_{3}\right)$ dengan Ketepatan Passing (Y), diperoleh koefisien korelasi sebesar 0.491. Dengan $\mathrm{N}=30$, nilai $r_{\text {tabel }} \%=0,361$. Ternyata $r_{\text {hitung }}=0.491>r_{\text {tabel } 5 \%}=0,361$. Hal ini menunjukkan bahwa terdapat hubungan yang signifikan antara Kelentukan $\left(\mathrm{X}_{3}\right)$ dengan Ketepatan Passing (Y).

Ringkasan hasil analisis korelasi masing-masing prediktor dengan kriterium penelitian ini adalah sebagai berikut: 
Tabel 6. Rangkuman Hasil Analisis Korelasi Tiap Prediktor dengan Kriterium

\begin{tabular}{|c|c|c|c|}
\hline Variabel & $\mathrm{r}_{\text {hitung }}$ & $\mathrm{r}_{\text {tabel }}$ & Simpulan \\
\hline $\mathrm{X}_{1} \mathrm{Y}$ & 0.426 & 0,361 & Korelasi signifikan \\
\hline $\mathrm{X}_{2} \mathrm{Y}$ & 0.494 & 0,361 & Korelasi signifikan \\
\hline $\mathrm{X}_{3} \mathrm{Y}$ & 0.491 & 0,361 & Korelasi signifikan \\
\hline
\end{tabular}

\section{Analisis Regresi}

Analisis regresi yang dilakukan pada penelitian ini menggunakan analisis regresi ganda tiga prediktor. Hasil analisis regresi antara data tes Kelentukan $\left(\mathrm{X}_{1}\right)$, Kekuatan Otot Tungkai $\left(\mathrm{X}_{2}\right)$, Keseimbangan Dinamis $\left(\mathrm{X}_{3}\right)$ Kelentukan dengan Kemampuan Passing (Y) penelitian ini adalah sebagai berikut:

a. Persamaan garis regresinya adalah:

$$
\hat{\mathrm{y}}=-0.184 \mathrm{X} 1+-0.040 \mathrm{X} 2+0.246 \mathrm{X} 3+8.154
$$

b. Koefisien korelasi dan determinasi antara prediktor dan kriterium:

$\mathrm{R}_{\mathrm{y}(1,2,3)}=0.668$

$\mathrm{R}_{\mathrm{y}(1,2,3)}^{2}=0.447$

c. Uji signifikansi analisis regresi.

Hasil uji signifikansi regresi penelitian ini dapat dilihat pada tabel berikut :

Tabel 7. Ringkasan Hasil Analisis Regresi

\begin{tabular}{|c|c|c|c|c|}
\hline Sumber Variasi & db & JK & RK & Freg \\
\hline Regresi (reg) & 3 & 39.0926 & 13.0309 & 7.0183 \\
\hline Residu (res) & 26 & 48.2741 & 1.8567 & - \\
\hline Total & 29 & 87.3667 & - & - \\
\hline
\end{tabular}

Dari hasil analisis regresi tersebut dapat disimpulkan, dengan db $=\mathrm{m}$ lawan $\mathrm{N}-\mathrm{m}-1=3$ lawan 26, harga $\mathrm{F}_{\text {tabel } 5 \%}$ adalah 2,89. Sedangkan nilai $\mathrm{F}$ yang diperoleh adalah 7.0183 , ternyata lebih besar dari angka Jurnal IImiah SPIRIT, ISSN; 1411 - 8319 Vol. 20 No. 1 Tahun 2020 
batas penolakan hipotesa nol. Dengan demikian hipotesa nol ditolak, yang berarti bahwa terdapat hubungan yang signifikan antara Kekuatan Otot Tungkai $\left(\mathrm{X}_{1}\right)$, Keseimbangan Dinamis $\left(\mathrm{X}_{2}\right)$, Kelentukan $\left(\mathrm{X}_{3}\right)$ dengan Kemampuan Passing (Y). Adapun besarnya nilai $\mathrm{R}^{2}$ antara Kekuatan Otot Tungkai $\left(\mathrm{X}_{1}\right)$, Keseimbangan Dinamis $\left(\mathrm{X}_{2}\right)$, Kelentukan $\left(\mathrm{X}_{3}\right)$ dengan KetepatanPassing $(\mathrm{Y})$ adalah 0,447.

\section{E. Pengujian Hipotesis dan Pembahasan}

\section{Hubungan Antara Kekuatan Otot Tungkai dengan KetepatanPassing}

Dari hasil analisis korelasi pada dataKekuatan Otot Tungkai dengan Kemampuan Passing, diperoleh nilai $\mathrm{r}$ sebesar 0.426, dimana nilai tersebut lebih besar dari nilai $r_{\text {tabel }}$ pada taraf signifikansi $5 \%$ yaitu 0,361. Karena nilai $r_{\text {hitung }}>r_{\text {tabel }}$, maka nilai korelasi signifikan. Hal ini berarti bahwaperubahan variansi KetepatanPassing dipengaruhi oleh komponen variansi Kekuatan Otot Tungkai.

\section{Hubungan Antara Keseimbangan Dinamis dengan KetepatanPassing}

Berdasarkan hasil analisis yang telah dilakukan terhadap data Keseimbangan Dinamis terhadap KetepatanPassing, diperoleh nilai r sebesar 0.494, dimana nilai tersebut lebih besar dari nilai $r_{\text {tabel }}$ pada taraf signifikansi $5 \%$ yaitu 0,361. Karenanilai $r_{\text {hitung }}<r_{\text {tabel }}$, maka nilai korelasi signifikan. Hal ini berarti bahwa variansi unsur Keseimbangan Dinamis berpengaruh terhadap peningkatan variansi KetepatanPassing.

\section{Hubungan Antara Kelentukan dengan KetepatanPassing}

Berdasarkan hasil analisis yang telah dilakukan terhadap data Kelentukanterhadap KetepatanPassing, diperoleh nilai $\mathrm{r}$ sebesar 0.491, dimana nilai tersebut lebih besar dari nilai $r_{\text {tabel }}$ pada taraf signifikansi $5 \%$ yaitu 0,361. Karenanilai $r_{\text {hitung }}>r_{\text {tabel}}$, maka nilai korelasi signifikan. Dengan demikian dapat disimpulkan bahwa Kelentukan memiliki hubungan yang signifikan terhadap KetepatanPassing.

4. Hubungan Kekuatan Otot Tungkai, Keseimbangan Dinamisdan Kelentukan dengan KetepatanPassing 


\section{Hubungan Antara Kekuatan Otot Tungkai keseimbangan Dinamis Dan Kelentukan dengan Ketepatan passing Sepakbola Pada Pemain putra umur 14-15 Tahun Klub SSB Angkasa Solo Tahun 2019 (Risa Agus Teguh Wibowo)}

Pada Hipotesis dinyatakan bahwa hubungan antara Kekuatan Otot Tungkai, Keseimbangan Dinamisdan Kelentukan dengan KetepatanPassing di ketahui $\mathrm{R}_{\mathrm{y}(123)}^{2}=0,447$ sedangkan $\mathrm{r}_{\text {tabel }}$ pada taraf signifikasi 0,05 dan $\mathrm{n}=30$ di dapat $\mathrm{r}_{\text {tabel }}$ $=0,361$, dengan hasil tersebut $r_{\text {hitung }}>r_{\text {tabel5 } \%}$ dan $f_{\text {hitung }}=7.0183$, sedangkan $f_{\text {tabel5\% }}$ dengan db 3:26 $=2,89$, ini berarti $\mathrm{F}_{0}>\mathrm{F}_{\text {tabel5\% }}$ Maka hipotesis di terima.

\section{SIMPULAN}

Berdasarkan hasil penelitian dan hasil analisis regresi dan korelasi product moment yang telah dilakukan dapat diperoleh simpulan sebagai berikut:

1. Ada hubungan signifikan antara Kekuatan Otot Tungkai dengan Ketepatan Passing, rhitung $=0.426>$ rtabel $5 \%=0,361$.

2. Ada hubungan signifikan antara Keseimbangan Dinamis dengan Ketepatan Passing, rhitung $=0.494>$ rtabel $5 \%=0,361$.

3. Ada hubungan signifikan antara Kelentukan dan Ketepatan Passing termasuk data inversi (lebih kecil dari $\mathrm{r}$ tabel, rhitung) $=0.491>$ rtabel $5 \%=0,361$.

4. Ada hubungan yang signifikan antara Kekuatan Otot Tungkai, Keseimbangan Dinamis dan Kelentukan dengan Ketepatan Passing, R2y(123) sebesar 0,447 $>$ rtabel5 \% pada taraf signifikansi 5\% sebesar 0.361 dan F0 sebesar $7.0183>$ ftabel pada taraf signifikansi $5 \%$ sebesar 2,89.

\section{DAFTAR PUSTAKA}

Dwi Hatmisari Ambarukmi. 2010. Pelatihan Olahraga anak usia dini. Jakarta : ASDEP Pengembangan tenaga dan pembina keolahragaan deputi bidang peningkatan prestasi dan IPTEK olahraga kementerian negara pemuda dan olahraga.

Hamidsyah Noer.1996. Ilmu Kepelatihan Lanjut. Surakarta : Universitas Sebelas Maret Surakarta.

Harsono. 2001. Latihan Kondisi Fisik. Bandung : Universitas Pendidikan Indonesia. 
Imam Imanudin. 2008. Ilmu Kepelatihan Olahraga. Bandung : Universitas Pendidikan Indonesia.

Ismaryati. 2008. Tes dan Pengukuran Olahraga. Surakarta : UNS Press.

Kadir Jusuf. 1982. Sepakbola Indonesia. Jakarta : PT. Gramedia.

Luxbacher, J. A. 2012. Sepak Bola : Langkah-Langkah Menuju Sukses. Terjemahan. Agsuta Wibawa. Jakarta : Rajawali Pers.

Marta Dinata. 2007. Dasar-dasar Mengajar Sepakbola. Jakarta : Cerdas Jaya 